\title{
Community health care and belief system associated with selected plant species by Mao-Naga community in Manipur, India
}

\author{
Kreni Lokho ${ }^{1}$ and D. Narasimhan \\ Department of Botany, Madras Christian College (affiliated to University of Madras), Tambaram, \\ Chennai-600059, Tamil Nadu, India \\ ${ }^{1}$ Corresponding author: lokhokp@gmail.com \\ [Received 03.06.2019; Revised 21.06.2019; Accepted 24.6.2019; Published 30.06.2019]
}

\begin{abstract}
Plants are the backbone for life on earth and are essential for humans' survival. The study was carried out on Mao-Naga community of Manipur, India during the years 2015 - 2019. This paper presents eight indicator plants observed by the community in relation to health hazards for taking necessary precautions as preventive measure. The practices associated with this belief system are still in vogue. These belief systems based on understanding of nature portrays the concept of Human-Plant interaction and is an important aspect of cultural ecosystem services.
\end{abstract}

Key words: Traditional Knowledge, Healthcare, Mao-Naga, Indicator plant, Time

\section{INTRODUCTION}

"Time provide unified commands across temporal, spatial and cognitive scales to guide individual and collective human activities" F. Merlin Franco (2015)

Interaction between humans and plants are critical to the progress of human civilization. Plants also play an important role for terrestrial biodiversity and ecosystem functioning (Tasser et al. 2010). The long term interactions have led to the formation of informal and formal knowledge systems on food and medicines through trial and error method (Berkes et al. 2000; Nath \& Jain 2015; Jamshidi-Kia et al. 2018). Though the focal point in each tradition is the healing, the methodology of healing differs in its approach and perceptions of plants for human well-being based on geographical and cultural differences. These approaches are well documented from the early civilizations and curated in time by the herbalists, naturalists and researchers.

The concept of healing is both physiological and psychological in nature. These coherent practices enable human adaptability to nature and its variations (Wikström et al. 2012; Wohlwill 1974). The present study was based on the psychological perspective where plants are used as indicator that represent visual icons to the community for dissemination. The usage of plant as an indicator dates back early 300 B.C., and in fact, Theophrastus and Pliny used plants for predicting soil conditions. In the medieval times, Tragus and Cordus described plants as indicators with reference to ecology and soil (Greene 1870; Sampson 1939). The concept of indicators is refined over a period for more inclusiveness. Some of the examples are, lichens as an indicator for air pollution (Ferry et al. 1973); plants as indicators for agricultural activities and seasons (Samati \& Begum 2006; Mao \& Hynniewta 2011); algae as bioindicator for water quality (Bellinger \& Sigee 2010); and plants in relations to human emotions (Franco \& Narasimhan 2012). One of the well documented associations is pertaining 
to observation on plants in relation to illness, especially the pollen allergy (Charpin et al. 1993; Puc 2003; Oh 2018).

\section{The Mao-Naga Community}

Mao-Naga, a subtribe of Naga, inhabits the Senapati district of Manipur in the North-Eastern India. Mao-Nagas live in fifty-eight villages of which thirty-eight are revenue villages and twenty are functioning as semi-autonomous areas (Kapesa 2017). The study area falls between $24.37^{\circ}$ North latitude and $93.29^{\circ}$ E to $94.15^{\circ}$ E longitudes. It covers a geographical area of $3271 \mathrm{sq} \mathrm{km}$. According to National census commission of India, 2011, the total population of Mao-Naga population is 11500 (Census 2011). The annual rainfall of the region is between $671 \mathrm{~mm}$ to $1454 \mathrm{~mm}$ (District Administration Senapati Manipur 2019). The community is primarily dependent on agriculture. However, the community is also known as Ememei or Maos, the name Mao-Naga is the popular genre that is used to denote this particular community.

\section{MATERIALS AND METHODS}

The present fieldwork was carried out from December 2015 to January 2019. Open-ended interviews were used for the study and the data collected was supported by participant observation of the first author who is also a member of the same community. In addition to the primary data, telephonic conversation were made whenever there is need for additional information and this conversation were recorded for future reference. Madras Christian College under whose aegis the research was conducted does not have an ethics board. Hence, the code of the International Society of Ethnobiology (2006) was used as reference, and utmost care was taken to ensure that the study conforms to the code. Written Prior Informed Consent (PIC) was taken from the knowledge partners prior to the interview. Since the knowledge on which the study is carried out is in the public domain it is not attributed to any particular knowledge partner. However, a list of knowledge partners who interacted is provided.

Voucher specimens were collected and identified using relevant literature (Singh et al. 2000; Singh et al. 2000; Singh et al. 2001; Kanjilal et al.1934 - 1940; Hooker 1872 1897 ) as well as e-floras of China, Nepal and Thailand (www.efloras.org). Identifications were confirmed with the experts and nomenclature was updated by referring to the databases such as www.ars-grin.gov, www.efloras.org, www.tropicos.org, www.theplantlist.org, www.worldfloraonline.org. Voucher specimens have been deposited in ASSAM-Herbarium at Shillong. The plants have been enumerated by the botanical name, author citation, family, local name in italics and voucher specimen numbers. The belief system associated with the plants have been documented in detail with reasonable scientific accuracy.

\section{RESULTS AND DISCUSSION}

\section{Community health care and belief system}

1. Ageratina adenophora (Spreng.) R.M.King \& H.Rob. [Compositae]; Japan pro; KL 12478

The plant flowers during March and April, the period which the community acknowledges as the season for cough and cold. The reason attributed by the community for cough and cold during these months is that dry, dusty and windy climatic conditions and mild spell of rain from time to time. These changes in the weather contribute to the health issues in the community. 
During these months, people avoid harvesting honey as they believe that the bee stings are more painful than other period of the year. The practice acknowledges sustainable harvest of honey.

2. Betula alnoides Buch.-Ham. ex D.Don; [Betulaceae]; Pochüri bu; KL 12470 and Curcuma angustifolia Roxb. [Zingiberaceae]; Kodzüapa; KL 12376

Adults advised the youth to care themselves when the leaves of these plants turned yellow during the month of November. It is said that people are prone to sickness during this month. The belief system acknowledges the transition of autumn to winter, the drop in the temperature followed by cold winds and mild showers. The reduction in temperature weakens immune system response and allows more viral growth (Heid 2018).

\section{Centella asiatica (L.) Urb. [Apiaceae]; Koreio; KL 12723}

The plant is used as greens by the community whereas consuming of the plant growing in the swidden field is believed to make a person lethargic and prone to thirst. The notion behind the laziness might be an analogy for person who doesn't own a wet terrace field thereby depending on the produce of swidden fields for food source. It is observed that the plant in the swidden fields develops pubescent hairs - an adaptation of the plant to lower temperature and transpiration rate (Ehleringer \& Mooney 1978). These adaptation of the plant indicate less succulency which may result in triggerring of human thirst.

If the bitterness of the plant in the wet terrace paddy field exceeds than the normal, it is believed that the community will witness more verbal fight and bitterness within the villagers. The belief system alerts people on the changes in quality of food based on seasons and locations.

4. Prunus domestica L. [Rosaceae]; Haikha; KL 12420 and Prunus persica (L.) Batsch [Rosaceae]; Mikrashü; KL12458

The ripening $P$. persica begins in the first week of May whereas $P$. domestica fruits in mid of May. There is a song my late grandmother used to sang when I was young, 'Haikha rashii tole tili, kali-kahei koto kojii no, kosii-padei tole tili cholera, cholera loti ledo' meaning if you want to eat $P$. domestica fruits, eat one or two, if you ate three or four you will get cholera. The song denotes about health issues, biological changes it generates in one's body and disseminating the traditional knowledge through a musical tradition. Thereby, adults advised the children to consumed fruits to satisfy their craving during the initial harvest of the fruit. The first formed fruits of the season are attractive to frugivores and insects which might cause infestations of pathogens.

\section{Persicaria arifolia (L.) Haraldson [Polygonaceae]; Mario; KL 12771}

Consuming of the plant before the heavy rain during February is believed to acquire infection on the skin, locally termed as Mario ra soruwe. The symptoms include intense itching with burning sensation or blister formation. The harvest and processing of paddy during winter facilitates the husk to settled down on the plants around the fields. Consuming the plant before the rain water washed away the husk of paddy seeds leads to ill health.

\section{Schima wallichii Choisy [Theaceae]; Chükhei sü; KL 12715}

Falling off of the flowers upside down is believed to result in more eloping among men. The falling of flowers occurs during the paddy plantation (June and July) - the busiest 
months for the community where old or folks on a voluntary basis sleeps in the paddy fields huts to save time and energy in travelling. The absence of their parents allows ample time for the lovers. Eloping is a social taboo and there are incidents of forfeiting wealth and gifts from the parents due to eloping which further affected the family life during yester decades.

\section{CONCLUSION}

From the present study, it becomes clear that the calendar information is disguised as plant indicators which act as a visual reminder to the community. It is rightly said that time commands collective actions of human activities (Prober et al. 2011; Franco 2015). The information on the indicator plants used by Mao-Naga community for their health and social care systems may help to understand the relationship of humans and plants. Plants are treated in early Mao-Naga culture as an important visual signal to take care of the health and the society. In recent times, this precious traditional knowledge is eroding due to cultural diffusion that makes the youth to deem the traditional cultural practices as outdated. Many have moved to cities for jobs or studies, leaving the old folks and their stories to the grave.

\section{LITERATURE CITED}

Bellinger, E.G. \& Sigee, D.C. 2010. Freshwater Algae Identification and Use as Bioindicators. Oxford: John Wiley \& Sons.

Berkes, F.; Colding, J. \& Folke, C. 2000. Rediscovery of Traditional Ecological Knowledge as Adaptive Management. Ecol. Appl., 10 (5): 1251 - 1262. doi:10.2307/2641280

District Administration Senapati Manipur. 2019 (March 11). About District. Retrieved from Senapati District Manipur: https://senapati.nic.in/about-district/

Census 2011 (July 01). District Census Handbook - Manipur. Retrieved July 09, 2018, from Office of the Registrar General \& Census Commissioner, India: http:// www.censusindia.gov.in/2011 census/dchb/DCHB_A/ $14 /$ 1401_PART_A_DCHB_SENAPATI.pdf

Charpin, D.; Hughes, B.; Mallea, M.; Sutra, J. P.; Balansard, G. \& Vervloet, D. 1993. Seasonal allergic symptoms and their relation to pollen exposure in south-east France. Clinical and Experimental Allergy, 23 (5): 435 - 439.

http://www.efloras.org. [Retrieved on February 22, 2008].

Ehleringer, J.R. \& Mooney, H.A. 1978. Leaf Hairs: Effects on Physiological Activity and Adaptive Value to a Desert Shrub. International Association for Ecology, 37(2): 183 - 200. [Retrieved from https://www.jstor.org/stable/4215742]

Ferry, B.W.; Baddeley, M.S. \& Hawksworth, D.L. 1973. Air Pollution and Lichens. Toronto, Canada. University of Toronto Press.

Franco, F.M. 2015. Calendars and Ecosystem Management: Some Observations. Human Ecol., 43: 355 - 359.

Franco, F.M. \& Narasimhan, D. 2012. Ethnobotany of the Kondh, Poraja, Gadaba and Bonda of the Koraput region of Odisha, India. D.K. Print World, New Delhi.

Greene, E.L. 1870. Landmarks of Botanical History. Smithsonian Institution, P. 1 - 329.

https://www.ngpsweb.ars-grin.gov/gringlobal/taxon/taxonomysearch.aspx. [Retrieved on December 22, 2018.] 
Heid, M. 2018 (March 19). Are You More Likely to Get Sick When The Seasons Change? Here's What Experts Say. Retrieved from Time: http://time.com/5198318/seasonschanging-sick-cold/

Hooker, J.D. 1872-1897. The Flora of British India. Vols. 1 - 7. L. Reeve \& Co., London.

International Society of Ethnobiology. 2006. International Society of Ethnobiology Code of Ethics. Retrieved 2008, from http://ethnobiology.net/code-of-ethics/(with 2008 additions)

Jamshidi-Kia, F.; Lorigooini, Z. \& Amini-Khoei, H. 2018. Medicinal plants: Past history and future perspective. J. Herbmed Pharm., 7(1): $1-7$.

Kanjilal, U. N.; Kanjilal, P. C.; Das, A. \& De, R. N. 1934-1940. Flora of Assam. Vols. I-IV. Goverment of Assam, Shillong.

Kapesa, A. 2017. Ethnographic study of the Mao Naga tribe of Manipur, India. International J. Adv. Res., 5(3): 1119 - 1124.

Mao, A. A. \& Hynniewta, T.M. 2011. Plants used as agricultural season's indicator by Mao Naga tribe, Manipur, India. Indian J. Trad. Knowl. 10(3): 578 - 580.

Nath, M. \& Jain, S.K. 2015. Some Medicinal Plants of Indian Purânas in Today's Ethnomedicinal Perspective. Indian J. Hist. Sci., 50(2): 196 - 207. doi:10.16943/ijhs/ 2015/v50i2/48235

Oh, J.-W. 2018. Pollen Allergy in a Changing World. Springer, Singapore.

Prober, S. M.; O'Connor, M. H. \& Walsh , F.J. 2011. Australian Aboriginal Peoples' Seasonal Knowledge: a Potential Basis for Shared Understanding in Environmental Management. Ecol. Soc. 16: 12.

Puc, M. 2003. Characterisation of pollen allergens. Ann. Agri. Eenv. Med. 10(2): 143-149.

Samati, H. \& Begum, S.S. (2006). Plant indicators for agricultural seasons amongst Pnar tribe of Meghalaya. Indian J. Trad. Knowl. 5(1): $57-59$.

Sampson, A.W. 1939. Plant Indicators: Concept and Status. Bot. Rev. 5(3): 155 - 206. Retrieved from https://www.jstor.org/stable/4353204

Singh, N.P.; Chauhan, A.S. \& Mondal, M.S. 2000. Flora of Manipur : Vol. 1 (Ranunculaceae Asteraceae). Botanical Survey of India, Calcutta.

Singh, N.; Singh, K.P. \& Singh, D. 2002. Flora of Mizoram, Vol. 1 (Ranunculaeae Asteraceae). Botanical Survey of India, Kolkota.

Tasser, E.; Niedrist, G.; Zimmermann, P. \& Tappeiner, U. 2010. Species Richness in Space and Time as an Indicator of Human Activity and Ecological Change. In: S.E. Jørgensen, F.L. Xu, \& R. Costanza (eds.), Handbook of Ecological Indicators for Assessment of Ecosystem Health Second edition. Taylor \& Francis Group, Florida. Pp. 149 - 165.

http://www.theplantlist.org. Retrieved December 29, 2018

http://www.tropicos.org. [Retrieved on May 03, 2019]

http:// www.worldfloraonline.org. Retrieved March 05, 2019

Wikström, B.-M.; Westerlund, E. \& Erkkilä, J. 2012. The healthcare environment-The importance of aesthetic surroundings: Health professionals' experiences from a surgical ward in Finland. Open J. Nurs., 2(3): 188-195. doi:10.4236/ojn.2012.23029

Wohlwill, J. F. 1974. Human Adaptation to Levels of Environmental Stimulation. Human Ecol. 2(2): 127-147. doi:10.1007/BF01558117. 